\title{
The importance of clinical approach in aggravated sexual abuse: Case report
}

\author{
Gökmen Karabağ, M.D., ${ }^{1}$ - Halil İbrahim Tanrıverdi, M.D., ${ }^{2}$ @ Mehmet Sunay Yavuz, M.D., ${ }^{1}$

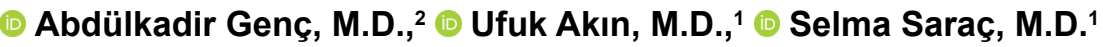

\author{
1Department of Forensic Medicine, Manisa Celal Bayar University Faculty of Medicine, Manisa-Turkey \\ ${ }^{2}$ Department of Pediatric Surgery, Manisa Celal Bayar University Faculty of Medicine, Manisa-Turkey
}

\begin{abstract}
The reported rate of sex crimes, some of the most severe acts of violence that can be perpetrated against an individual, is increasing across all societies, regardless of gender or age of the victim. Sexual abuse has been defined, in part, as the involvement of a child in sexual activity for which they are incapable of giving consent, that they cannot fully comprehend, or for which they are developmentally immature. Molestation of the anorectal region is frequently encountered when the victim of sexual abuse is a male child. Tenderness around the anus, ecchymosis, and detachment in the anal sphincter and rectum mucosa may be observed in the acute examination of children who have been subjected to aggravated sexual abuse; however, injuries related to the anus or the rectum may also occur as a result of an accident. An II-year-old male patient was referred from another health center with a report of being at risk of death. The injury that was said to be the result of accidentally sitting on a knife. An examination in the lithotomy position revealed perianal ecchymosis, a superficial laceration at $\mathrm{I}$ and 6 o'clock, and a deep laceration at 7 o'clock. Based upon a suspicion of sexual abuse, anal and rectal swab specimens were obtained. The pediatric surgery department performed a primary repair of the lacerations. The microscopic examination of the swab specimens revealed cells showing sperm morphology, and therefore the appropriate forensic statements were made and the swab specimens were sent to the judicial authority for genetic analysis. This report emphasizes the importance of the awareness of physicians regarding the prompt collection and submission of potentially evidential biological samples in a case of suspected sexual abuse though it may be presented as an accident.
\end{abstract}

Keywords: Biological sample; forensic medicine; sexual abuse.

\section{INTRODUCTION}

The reported number of sex crimes, which are among the most serious crimes that may committed against an individual, has been increasing in recent years, with victims of both sexes and from all age groups. ${ }^{[1,2]}$ Acts of sexual abuse against males are most often seen in childhood, especially in the puberty phase, when psychosexual development has occurred. [3-5] Sexual abuse cases are assessed on a broad spectrum, from the level of basic contact to penetration. If the victim is a male child, in most cases, the exploiter uses the anorectal region for sexual intercourse. ${ }^{[3,6]}$ In the examination of these cases, physicians may observe acute symptoms, such as ecchymosis around the anus and laceration of the sphincter or rectum; however, similar lesions might also be seen in cases of accidents. ${ }^{[7]}$ In the differential diagnosis between lacerations and incised wounds, tissue bridging is present in laceration injuries, and is typically accompanied by irregular wound edges and ecchymoses, while sharp object injuries do not demonstrate these characteristics. ${ }^{[8,9]}$

This case of apparent aggravated sexual abuse presented with an anamnesis of an accident. It emphasizes the importance of the clinical physicians' approach algorithms when encoun-

Cite this article as: Karabağ G, Tanrıverdi Hİ, Yavuz MS, Genç A, Akın U, Saraç S. The importance of clinical approach in aggravated sexual abuse: Case report. Ulus Travma Acil Cerrahi Derg 2018;24:597-600.

Address for correspondence: Gökmen Karabağ, M.D.

Manisa Celal Bayar Üniversitesi, Dekanlık Binası, Adli Tıp Anabilim Dalı, Uncubozköy, 45030 Manisa, Turkey

Tel: +90236 - 2011000 E-mail: gkmnkrbg@gmail.com

Ulus Travma Acil Cerrahi Derg 2018;24(6):597-600 DOI: 10.5505/tjtes.2018.60063 Submitted: 12.06.2018 Accepted: 28.08.2018 Online: 13.11.2018

Copyright 2018 Turkish Association of Trauma and Emergency Surgery 

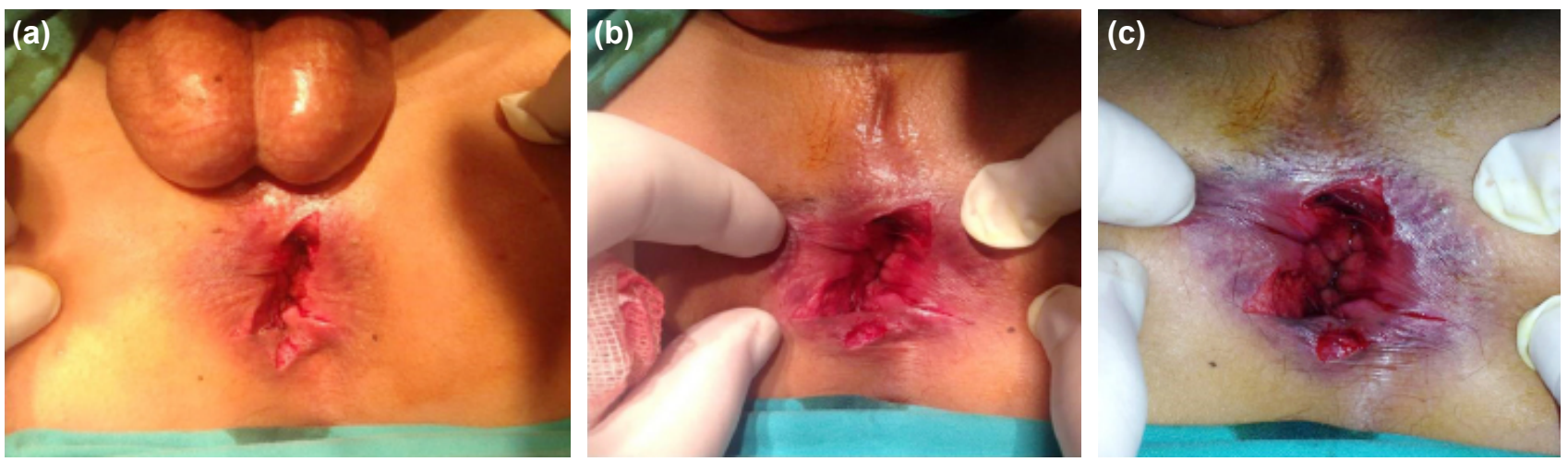

Figure 1. (a-c) Preoperative photograph of the patient.

tering symptoms of possible sexual abuse and highlights the importance of properly obtaining samples that might be considered evidence.

\section{CASE REPORT}

An II-year-old male patient who had presented at another health care center with the statement of having sustained an accidental injury as the result of accidentally sitting on a knife was sent to our hospital on the same day with a statement that he could be at grave risk. The general examination indicated that the patient was conscious, cooperative, and had stable vital signs. An anal examination of the patient in the lithotomy position revealed a $1.5-\mathrm{cm}$ superficial laceration at the I o'clock position that passed through the dentate line with involvement of the mucosa; another superficial laceration approximately $\mathrm{I} \mathrm{cm}$ in length at the 6 o'clock position, also involving the mucosa, but not crossing the dentate line; a 3-cm long area of deep lacerations at the 7 o'clock position that passed through dentate line and included the mucosa and some parts of the lower internal sphincter; an ecchymotic halo around the anus; and a significant reduction in anal sphincter tone (Fig. Ia-c). Outside of the anorectal region, there were no trauma marks or visible injuries to the body. $A$ swab was taken from the anus and the rectum and analyzed microscopically (Fig. 2). Subsequently, following staining and sterile draping in the lithotomy position, the superficial lacerations at the I and 6 o'clock positions were primarily repaired with separate sutures under general anesthesia, and primary repair of the mucosa for the deep laceration at the 7 o'clock position was performed after the muscle layers were individually pulled together (Fig. 3). Subsequent examination with an anal stimulator indicated that contraction was present in all quadrants around the anus except at the site of the laceration line at 7 o'clock.

The results of Gram staining of samples from the laceration areas, perianal ecchymotic halo, and swab specimens revealed cells with sperm morphology, and accordingly, the case was processed as potential aggravated sexual abuse. The required forensic reports were completed and the samples obtained were sent to the office of the chief public prosecutor for genetic analysis.

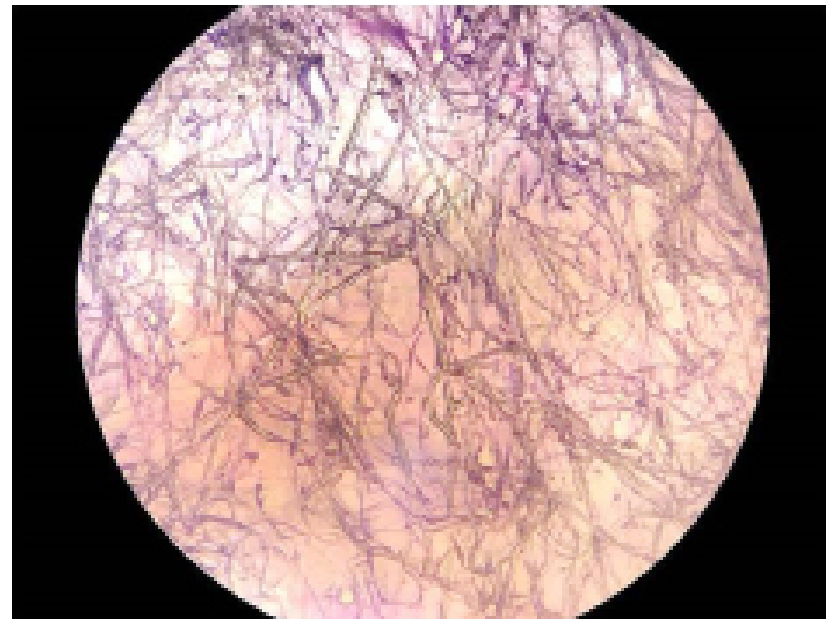

Figure 2. Sperm cells observed in the smear preparation from the anal swab sample.

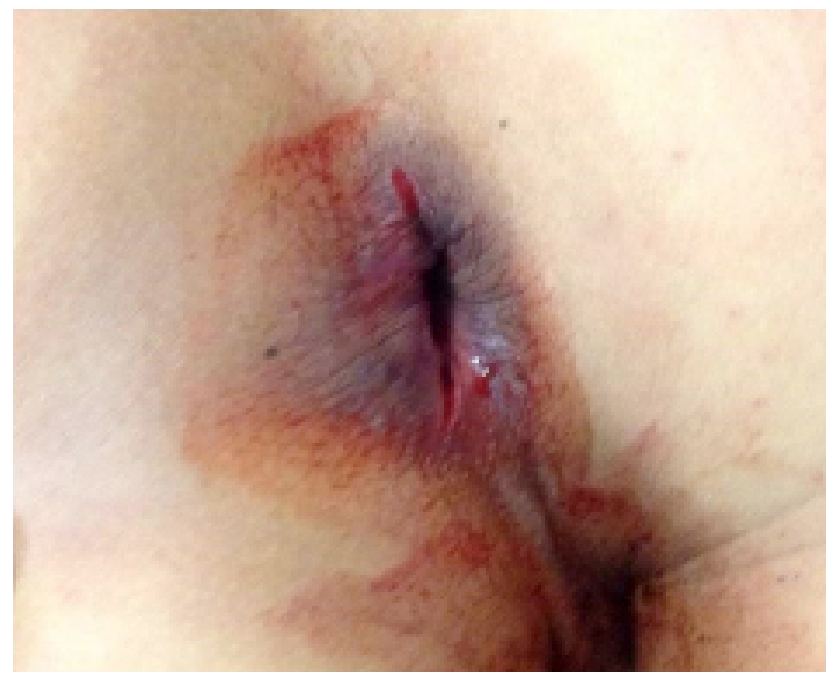

Figure 3. Postoperative photograph of the patient.

\section{DISCUSSION}

Child abuse, a serious problem that may have traumatic consequences for the physical, mental, and social development of victims, has been defined, in part, by the World Health Organization as acts and omissions committed by an adult, society, or state that affect the child's physical, psychological, 
and social development. ${ }^{[10]}$ Sexual abuse, defined within the category of child abuse, has been defined as the use of a child for sexual stimulation by an adult or another child. ${ }^{[1-13]}$

According Article 103 of the Turkish Penal Code, sexual abuse is defined as any sexual act committed against a minor under the age of 15, or one who, in spite of having reached I 5 years of age, lacks the competence to understand the legal significance and consequences of such acts, as well as sexual acts committed against minors by means of force, threat, deception or any other means of influence. Article 280 of the Turkish Penal Code states that health workers, such as doctors, nurses, and psychologists, etc., who suspect that an act of child abuse may have occurred are obliged to inform the appropriate authorities. ${ }^{[14]}$ Turkish healthcare professionals have ethical and legal obligations related to the diagnosis and treatment of child abuse and need to be well informed. ${ }^{[15]}$

The initial examination in the present case, which was presented with the anamnesis of accidental sitting on a knife, led the doctors to suspect aggravated anal sexual abuse based upon the observation of lacerations in 3 quadrants of the anal region that were unlike the laceration expected in a case of a perforating injury. Furthermore, observation of an ecchymotic halo around the anus and a significant reduction in anal sphincter tone strongly supported this suspicion. Therefore, photographs were taken and a swab specimen was collected pre-operatively, which yielded a result of cells with sperm morphology, further supporting the conclusion of aggravated anal sexual abuse. Prompt transmission of these evidential biological samples to the relevant judicial authorities to reduce any possibility of deterioration or loss is a good example of the use of the sexual abuse approach algorithm in the clinic.

Most cases of sexual violence are not reported to the judicial authorities due to social pressure and moral concerns. ${ }^{[3]}$ As in other cases of sexual abuse and assault, there is a tendency among male victims to conceal the event. ${ }^{[3,6]}$ Similarly, our patient had been trying to hide this act of sexual exploitation and stated that the injury to the anal region was the result of his own act of accidentally sitting on a knife.

It is crucial to follow a scientific, systematic, multidisciplinary, and robust approach to the prevention of violence, which is a multidimensional public health problem, just as it is in the case of other diseases. ${ }^{[16]}$ According to the 6th article of the Child Protection Law in our country, judicial and administrative authorities, law enforcement officers, health and education institutions, and non-governmental organizations are obliged to report children who need protection to the Social Services and Child Protection Agency. Both the child and the person responsible for the care of the child may apply to the Social Services and Child Protection Agency for the protection of the child. According to the $22^{\text {nd }}$ article of the Social Service Law, for children who need protection, the decision for any necessary relevant injunction can be made by the appropriate authorized court under the Child Protection Law No. 5395 of 03/07/2005 regarding the well-being of juveniles. Institutions and individuals who are responsible for the care of a juvenile can apply to the Social Services and Child Protection Agency to take the juvenile under protection and the case is sent to the relevant court. Children who urgently require preventive protective measures may be taken into custody and cared for by governmental or private organizations until the court decision. ${ }^{[17,18]}$

The objective of presenting this report of child sexual abuse in a patient who presented with an accident anamnesis was to illustrate the importance of the approach applied by physicians who suspect abuse and the appropriate collection and conveyance of evidential biological samples to judicial authorities.

\section{Conflict of interest: None declared.}

\section{REFERENCES}

1. Glover K, Olfson M, Gameroff MJ, Neria Y. Assault and mental disorders: a cross-sectional study of urban adult primary care patients. Psychiatr Serv 2010;61:1018-23. [CrossRef]

2. Luce H, Schrager S, Gilchrist V. Sexual assault of women. Am Fam Physician 2010;81:489-95.

3. Pınarbaşılı RDT, Özkök MS, Katkıcı U, Erel Ö, Dirlik M. Male sexual abuse in Aydın [Article in Turkish]. Adli Tip Bülteni 2003;8:41-7.

4. King M, Wollett E. Sexually assaulted males: 115 men consulting a counseling service. Arch Sex Behav 1997;26:579-88.

5. Kairys SW, Alexander RC, Block RW, Everret VD, Hymel KP, Johnson $\mathrm{CF}$, et al. Guidelines for the evaluation of sexual abuse of children. Pediatrics 1999;103:186-91. [CrossRef]

6. Bartuçu, Yavuz MF, Çetin G. Problems Faced by the Victims of Sexual Assault [Article in Turkish]. Adli Tip Bülteni 1999;4:41-53.

7. Koç S. Adli tıpta rapor hazırlama tekniği ve rapor örnekleri. In: Soysal Z, Çakalır C, editors. Adli Tıp. Volume III. İstanbul: İstanbul Üniversitesi Basımevi ve Film Merkezi; 1999. p. 1587-9.

8. DiMaio VJ, DiMaio D. Blunt trauma wounds. In: DiMaio VJ, DiMaio D, editors. Forensic Pathology. 2nd ed. London: CRC Press; 2001. p. 91-116. [CrossRef]

9. Prahlow JA. Sharp force injuries. In: Froede RC, editor. Handbook of Forensic Pathology. 2nd ed. Illinois: CRC Press; 2003. p. 159-73.

10. Polat O, İnanıcı MA, Aksoy ME. Adli Tip Ders Kitabı. İstanbul: Nobel Tip Kitabevleri; 1997.p. 291-2.

11. Tiraşçı $Y$, Gören S. Child Abuse and Neglect [Article in Turkish]. Dicle Tip Dergisi 2007;34:70-4.

12. Polat O. Adli Tip. İstanbul: Der Yayınlar1; 2000. p. 207-16.

13. Türk Tabipler Birliği. Çocuk istismarı ve ihmali. In: Birinci Basamak İçin Adli Tip El Kitabı. Nisan 1999. p. 135-46.

14. Türk Ceza Kanunu. Available at: http://www.mevzuat.gov.tr/MevzuatMetin/1.5.5237.pdf. Accessed Sep 3, 2018.

15. Ovayolu N, Uçan Ö, Serindağ S. Sexual Abuse in Child and Its Effects [Article in Turkish]. Firat Sağlık Hizmetleri Dergisi 2007;2:13-22.

16. Kara B, Biçer Ü, Gökalp AS. Child abuse [Article in Turkish]. Çocuk Sağlığı ve Hastalıkları Dergisi 2004;47:140-51.

17. Çocuk Koruma Kanunu. Available at: http://www.resmigazete.gov.tr/ eskiler/2005/07/20050715-1.htm. Accessed Sep 3, 2018.

18. Sosyal Hizmetler Kanunu. Available at: http://www.mevzuat.gov.tr/ MevzuatMetin/1.5.2828.pdf. Accessed Sep 3, 2018. 


\section{OLGU SUNUMU - ÖZET}

\section{Nitelikli cinsel istismarda klinik yaklaşımın önemi: Olgu sunumu}

\section{Dr. Gökmen Karabağ,,$^{1}$ Dr. Halil İbrahim Tanrıverdi, ${ }^{2}$ Dr. Mehmet Sunay Yavuz,} Dr. Abdülkadir Genç, ${ }^{2}$ Dr. Ufuk Akın, ${ }^{1}$ Dr. Selma Saraç ${ }^{1}$

${ }^{1}$ Manisa Celal Bayar Üniversitesi Tıp Fakültesi, Adli Tıp Anabilim Dalı, Manisa ${ }^{2}$ Manisa Celal Bayar Üniversitesi Tıp Fakültesi, Çocuk Cerrahisi Anabilim Dalı, Manisa

Bireye karşı işlenen en ağır eylemlerden olan cinsel suçlar, cinsiyet ve yaş farkı gözetmeksizin giderek tüm toplumlarda artış göstermektedir. Çocukların cinsel istismarı; gelişimsel olarak olgunlaşmamış çocukların, bilinçli bir şekilde onay vermeye muktedir olmadıkları ve bütünüyle algılayamadıkları cinsel aktivitelerde taraf olmalarıdır. Cinsel istismarda anorektal bölgenin kullanılması sıklıkla erkek çocukların kurban olduğu olaylarda karşımıza çıkmaktadır. Anal yoldan nitelikli cinsel istismara uğrayan çocukların yapılan muayenesinde; akut bulgu olarak anüs etrafında hassasiyet, ekimoz, anal sfinkterde ve rektum mukozasında yırtılmalar görülebilmekle birlikte; kaza sonucu da anüs veya rektumu ilgilendiren yaralanmalar oluşabilir. Bıçağın üzerine oturma sonucu yaralandığı ve hayati tehlikesi olduğu için dış merkezden hastanemize yönlendirilen II yaşında erkek olgunun litotomi pozisyonunda yapılan muayenesinde; perianal ekimoz, saat bir ve altı hizasında yüzeyel, saat yedi hizasında derin laserasyon hattı görülmüş, cinsel istismardan şüphelenilmesi üzerine anüs ve rektumdan sürüntü örnekleri alınmış, daha sonra çocuk cerrahisi tarafından operasyona alınarak laserasyonlar primer olarak onarılmıştır. Alınan sürüntülerden hazırlanan preparatın mikroskopik incelemesinde sperm morfolojisine sahip hücreler izlenmiş ve adli bildirim yapılarak alınan örnekler genetik çalışmalar için ilgili yargı makamına gönderilmiştir. Çalışmamızda, kaza öyküsü ile başvuran fakat yapılan muayenelerinde nitelikli cinsel istismardan şüphelenilenmesi üzerine operasyon öncesi örnekleri alınan bir olgu sunularak, klinikte cinsel istismardan şüphelenen hekimlerin olguya bakış açııı, delil niteliğinde sayılabilecek biyolojik materyallerin bozulmadan ve kaybolmadan elde etmenin ve ilgili adli makamlara ulaştırmanın önemi vurgulanmıştır.

Anahtar sözcükler: Adli tıp; biyolojik örnek; cinsel istismar.

Ulus Travma Acil Cerrahi Derg 2018;24(6):597-600 doi: 10.5505/tites.2018.60063 